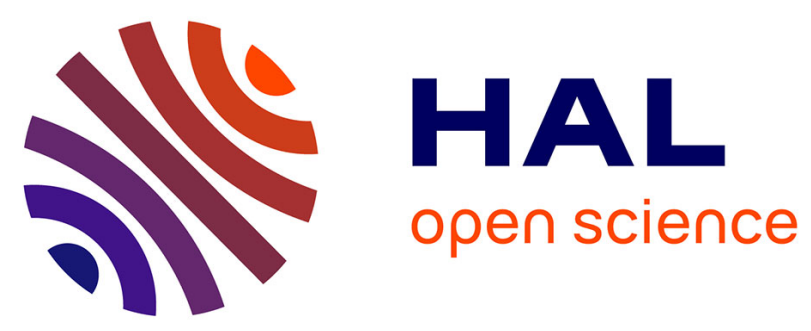

\title{
Sand-mud transition dynamics at embayed beaches during a typhoon season in eastern China
}

Junli Guo, Lianqiang Shi, Shenliang Chen, Bruno Castelle, Yang Chang, Wufeng Cheng

\section{- To cite this version:}

Junli Guo, Lianqiang Shi, Shenliang Chen, Bruno Castelle, Yang Chang, et al.. Sand-mud transition dynamics at embayed beaches during a typhoon season in eastern China. Marine Geology, 2022, 441, pp.106633. 10.1016/j.margeo.2021.106633 . hal-03411335

\section{HAL Id: hal-03411335 \\ https://hal.science/hal-03411335}

Submitted on 2 Nov 2021

HAL is a multi-disciplinary open access archive for the deposit and dissemination of scientific research documents, whether they are published or not. The documents may come from teaching and research institutions in France or abroad, or from public or private research centers.
L'archive ouverte pluridisciplinaire HAL, est destinée au dépôt et à la diffusion de documents scientifiques de niveau recherche, publiés ou non, émanant des établissements d'enseignement et de recherche français ou étrangers, des laboratoires publics ou privés. 
1 Sand-mud transition dynamics at embayed beaches during a typhoon season in eastern China

3 Junli Guo a, Lianqiang Shi ${ }^{\text {b,c }}$, Shenliang Chen ${ }^{\text {a, * }}$, Bruno Castelle ${ }^{\mathrm{d}, \mathrm{e}}$, Yang Chang ${ }^{\text {a }}$, Wufeng Cheng a a. State Key Laboratory of Estuarine and Coastal Research, East China Normal University, Shanghai 200241, China

b. Second Institute of Oceanography, Ministry of Natural Resources of China, Hangzhou, 310012, China

c. Fourth Institute of Oceanography, Ministry of Natural Resources of China, Beihai, 536000, China

d. CNRS, UMR EPOC, Pessac, France

e. Université de Bordeaux, UMR EPOC, Pessac, France

*Corresponding author.

E-mail address: slchen@sklec.ecnu.edu.cn (S. Chen)

Abstract: Sand-mud transition (SMT) is an important boundary of the beach system, and its location and evolution have been increasingly studied in recent years. This study focuses on the location and migration of SMTs and their influencing factors on three representative embayed beaches on the east coast of Zhujiajian Island, Zhejiang Province, China, characterized by different levels of human interventions. Beach topographies, surficial sediment characteristics and nearshore hydrodynamic data were 
obtained through three field campaigns carried out during the early, middle and late stages of the 2019 typhoon season. This typhoon season included four typhoons with nearshore significant wave height $H_{s}$ exceeding $3.71 \mathrm{~m}$, and maximum $H_{s}$ of $6.77 \mathrm{~m}$ (Super Typhoon Lekima). Results show that the three beaches were all impacted by the high-energy wave conditions, although with some different behaviors. Sediments of the three beaches all coarsened with worse sorting during the typhoon season, with the nearshore surficial sediments showing similar patterns. The SMTs of the three beaches were stable or migrated seaward during the typhoon season. During the typhoon season, offshore SMT migration was positively correlated with the beach profile volumetric loss at three embayed beaches in this study. The SMTs of beaches with less human intervention are more stable during typhoon season. By including 12 additional embayed beaches of eastern China in our analysis, we found that the SMT offshore distance increases with increasing nearshore average significant wave height, increasing headland offshore extent and decreasing tidal range. Our study suggests that SMT is a relevant indicator of beach sediment stability, which can help to increase the understanding of embayed beach dynamics and to guide coastal management and planning during typhoon seasons at such embayed beaches.

Keywords: Embayed beaches; sand-mud transition (SMT); human intervention; typhoon season; beach stability

\section{Introduction}

The concept of sand-mud transition (SMT) was first proposed by McCave (1972) 
and Stanley and Wear (1978) based on changes in the grain size of surficial sediments, defined where the mean grain size is $63 \mu \mathrm{m}(4 \Phi)$ or the mud content is $25 \%$. The differences in the biological, physical, geological, and chemical processes between its two sides make the SMT a particularly important boundary (George et al., 2007). Generally, all coasts have one or more SMTs while progressively moving offshore, but their offshore distance and water depth vary considerably in different seas (George and Hill, 2008). The location of the SMT and its water depth are closely related to the hydrodynamic forcing (Dunbar and Barrett, 2005; George and Hill, 2008; Stanley and Moore, 1983), sediment supply (Chang et al., 2017; Edwards, 2002; George and Hill, 2008; Zhao et al., 2020a), and beach morphological changes (Zhao et al., 2020b).

Sandy coasts account for approximately $31 \%$ of the global ice-free coasts and have high socio-economic and ecological values (Luijendijk et al., 2018). Previous studies on beach morphodynamics mainly focused on storm-driven beach erosion (Ge et al., 2017; Qi et al., 2010), beach equilibrium planform (Castelle et al., 2020; Dai et al., 2007; Li et al., 2021; López et al., 2020), beach responses to human interventions (Cai et al., 2011; Castelle et al., 2009; Chiva et al., 2018; Cooke et al., 2012; Hamm et al., 2002; Hanson et al., 2002; Luo et al., 2016) or beach stability (Hudson and Baily, 2018; Liu et al., 2019). The SMT is closely related to beach morphodynamics, and its landward migration (Zhao et al., 2020a) has gradually attracted the attention of coastal managers and researchers.

Earlier SMT research focused on the location and depth of SMT and their influencing factors. SMT locations detected at the Monterey Bay in the United States 
showed the contrasting effects of storm- versus fluvial-dominated conditions on sedimentation (Edwards, 2002). Then, a more comprehensive study about SMT water depth and hydrodynamic conditions in different regions showed that change in SMT depth is mainly controlled by wave-induced bottom shear stress and a functional equation for estimating the SMT water depth using wave energy (Dunbar and Barrett, 2005). Controls on SMT depth were hypothesized using a large number of wave data on 14 sites around the world (George and Hill, 2008). The dynamic changes of sediments and topography of Dongsha beach at Zhujiajian Island, Zhejiang Province, China suggested that the SMT migrates seasonally, which was the first research on SMT migration in China (Cheng et al., 2014). Meanwhile, there are a large number of studies focusing on the SMT of sandy-muddy beaches. Different geomorphological stages of the sandy-muddy beaches with various SMT migrations are closely related to the enrichment of fluvial sediment and nearshore mud near the Amazon River estuary (Anthony et al., 2002; Anthony and Dolique, 2004), which was also confirmed on the west coast of North Korea (Chang et al., 2017). Changes in SMT depth of sandy-muddy beaches are mainly controlled by nearshore waves (Xu et al., 2018) and sediment supply (Zhou et al., 2019). The distribution and migration of SMT on sandy-muddy beaches in different estuaries and bays in southeastern China were further summarized by Zhao et al. (2020a, 2020b).

In the past few decades, approximately $50 \%$ of China's sandy coasts have been degraded due to erosion (Third Institute of Oceanography, 2010), and numerous protection practices have been implemented on beaches (Cai et al., 2011; Kuang et al., 
2019; Luo et al., 2016). The Zhoushan Archipelago is a popular tourist destination of Zhejiang Province, China, with more than 30 embayed beaches, of which the beaches on the east coast of Zhujiajian Island, are particularly famous (Xia, 2014). Typhoon is a common coastal disaster that affects the Zhoushan Archipelago, with an average of 6 typhoons per year (Lu, 2010), which has a significant impact on beach morphology and even threatens the tourism industry. The period from July to September each year is called the typhoon season, accounting for about $93 \%$ of the total number of yearly typhoon landfalls (Wang et al., 2011). However, the distribution and migration of SMTs on embayed sandy beaches during the typhoon season and their response to changes in beach morphology are still unclear, especially when they are also potentially affected by human activities.

In this study, three embayed sandy beaches (Dashali, Dongsha, and Qiansha) on the east coast of Zhujiajian Island, which are exposed to frequent storms and different human interventions, are studied. Changes in beach morphology and sediment characteristics during the 2019 typhoon season are analyzed. The temporal and spatial evolution of SMTs of embayed sandy beaches are explored and their driving factors are discussed.

\section{Regional setting}

The Zhujiajian Island is the fifth largest island in the Zhoushan Archipelago, Zhejiang Province, China (Fig.1a), with a land area of $62.2 \mathrm{~km}^{2}$ and a 79.2-km long coastline (Xia, 2014). The embayed beaches on the east coast of Zhujiajian Island are 
famous tourist destinations in China, of which Dashali, Dongsha, and Qiansha are representative beaches with different degrees of wave exposure and human interventions.

Dashali beach is located in the north of Zhujiajian Island, with a length of about $900 \mathrm{~m}$ and headlands at both ends extending approximately $600 \mathrm{~m}$ offshore (Fig. 1c). The Dashali beach slope ranges from $2.2 \%$ to $2.8 \%$, with an average slope of $2.4 \%$. Although there is a seawall backing Dashali beach, this beach still has well-preserved vegetated dunes. The median sediment grain size $\left(D_{50}\right)$ is between $2.12 \Phi$ to $2.74 \Phi$, and the sediment is mainly composed of fine sand.

Dongsha beach is a 1500-m long embayed sandy beach, with two headlands extending approximately $1350 \mathrm{~m}$ offshore (Fig. 1d). Beach slope ranges along the coast from $2.9 \%$ to $3.5 \%$, and surficial sediment $D_{50}$ is between $1.4 \Phi$ to $2.74 \Phi$. There were sand dunes at the back of the beach before 2012. The completion of the seawall in 2012 broke the balance of cross-shore sediment (Cheng et al., 2014), which further led to the disappearance of the dunes. The construction of seawalls and frequent storms resulted in dominant beach erosion for years (Guo et al., 2018). In order to fight against stormdriven erosion and increase the dry beach area, beach nourishments have been performed with a total of 52,000 $\mathrm{m}^{3}$ placed on Dongsha beach between 2016 and 2017 , with large impact on beach processes (Guo et al., 2020).

Qiansha beach is adjacent to the south side of Dongsha, with a total length of about $1200 \mathrm{~m}$, with headlands extending approximately $800 \mathrm{~m}$ offshore (Fig. 1e). Beach slope varies alongshore from $1.6 \%$ to $2.9 \%$, gradually decreasing southwards, with an 
average of $2.2 \%$. The beach is backed by cliff, with a few vegetated sand dunes. The surficial sediment $D_{50}$ is between $2.18 \Phi$ to $3.18 \Phi$. Amongst the three studied beaches Qiansha beach is the only natural beach without any coastal engineering work.

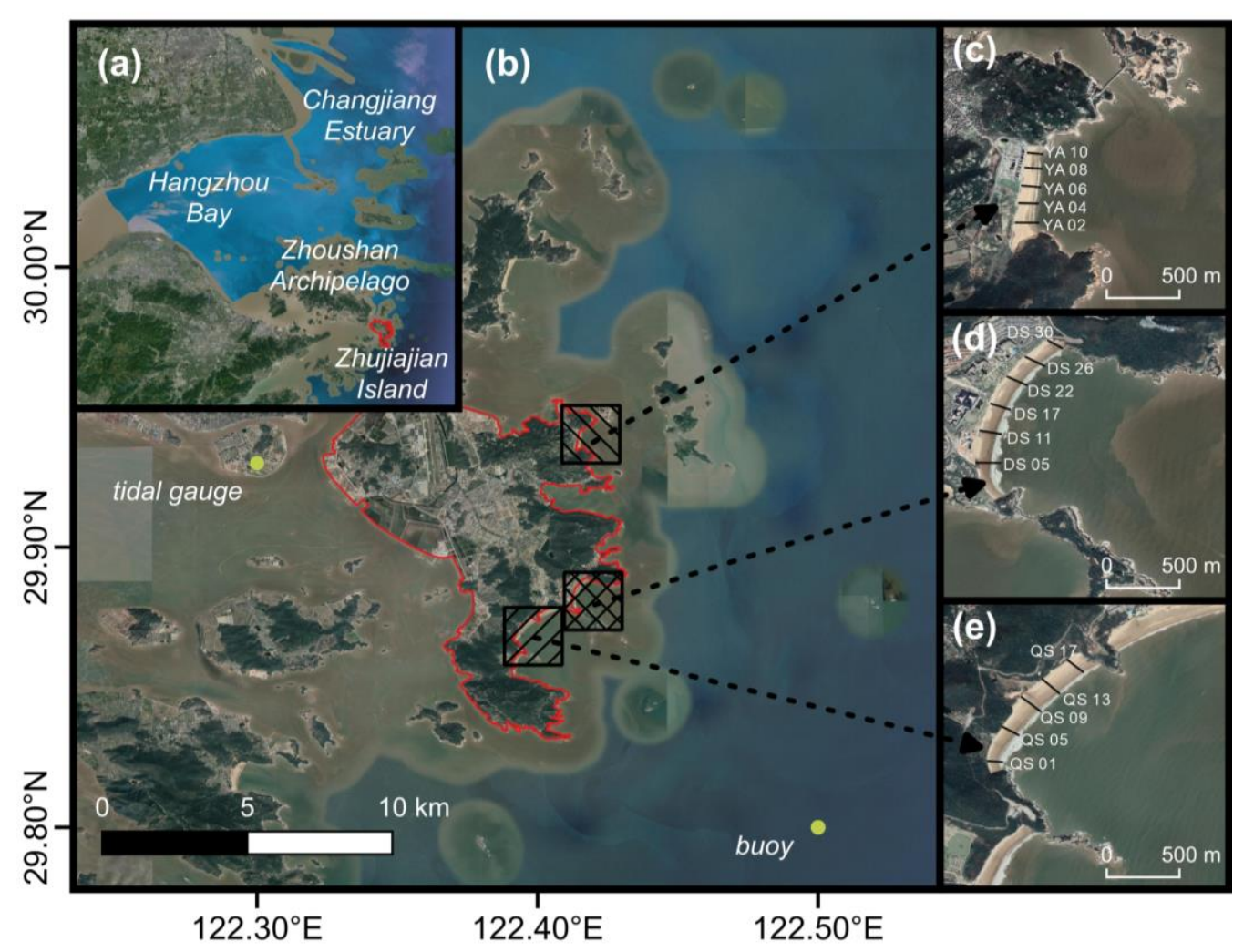

137 Fig.1 Sketch of study area: geographical locations of Zhuajiajian Island (a), tidal gauge

138 and buoy (b), Dashali beach (c), Dongsha beach (d), and Qiansha beach (e). The black

139 lines in (c, d, e) show the typical profile locations on each beach. The satellite image

140 was downloaded from Google Earth.

\section{Materials and methods}

\subsection{Hydrodynamic data}

The typhoon information was obtained from the National Meteorological Center

144 of China (http://typhoon.nmc.cn). From 1949 to 2019, a total of 46 typhoons reached 
Zhejiang Province, and 236 typhoons affected the coast of Zhejiang. The frequency of typhoons that have affected Zhejiang Province increased during the past decades (Guo et al., 2019). The main typhoon types are Severe Tropical Storms and Typhoons, with a few Super Typhoons. From July to September (typhoon season) each year, the typhoons that affect Zhejiang correspond to approximately $93 \%$ of the total (Wang et al., 2011).

The tidal data provided by the Shenjiamen Marine Station $\left(29.93^{\circ} \mathrm{N}, 122.3^{\circ} \mathrm{E}\right.$, Fig. 1b) shows that the tides in the Zhujiajian Island area are mainly semi-diurnal, with an average tidal range of $2.6 \mathrm{~m}$ (Xia, 2014). The wave data is obtained hourly from a wave buoy $\left(29.8^{\circ} \mathrm{N}, 122.5^{\circ} \mathrm{E}\right.$, Fig. $\left.1 \mathrm{~b}\right)$ located in approximately $20 \mathrm{~m}$ depth. The dominant wave direction in the study area is from the east, and the waves with larger significant wave heights mainly come from the directions between northeast and southeast (Guo et al., 2020). The maximum significant wave height observed by the wave buoy during the 2019 typhoon season was $6.77 \mathrm{~m}$.

\subsection{Topographic data}

To obtain the characteristics of topography and surficial sediment changes of Dashali, Dongsha, and Qiansha beaches and their nearshore area during typhoon season, we carried out three field campaigns on July 18, 2019, August 31, 2019, and September 24, 2019, representing the early, middle and late stages of the typhoon season, respectively. According to the individual characteristics of the three beaches, 10, 30, and 17 beach profiles are set up on Dashali, Dongsha and Qiansha (Fig. 1, Table 1), 
respectively. In addition, Dashali, Dongsha and Qiansha have five (YA02, YA04, YA06, YA08, YA10, see in Fig. 1c), six (DS05, DS11, DS17, DS22, DS26, DS30, Fig. 1d) and five (QS01, QS05, QS09, QS13, QS17, Fig. 1e) typical profiles, which include beach and nearshore surficial sediments. The beach topography was monitored at low tide using RTK GPS from the network of Continuously Operating Reference Stations

171 (CORS, with plane and vertical precisions of $\pm 8 \mathrm{~mm}$ and $\pm 15 \mathrm{~mm}$, respectively) with fixed-point measurements starting from the base (here, the base refers to a boundary between the sandy beach and cliffs/artificial seawall), and the elevation data of 171 profiles were all corrected to the Yellow Sea Datum 1985. typical cross-shore profile based on the shortest profile over the study period according to Burvingt et al.(2018):

$$
V_{\text {profile }}=\int_{z_{\min }}^{z_{\max }} z d z
$$

(Equation 1)

179 where $z$ corresponds to the topographic values interpolated every meter, and $z_{\min }$ and $180 z_{\max }$ are the lowest and the fixed backshore (seawall/cliff base) topographic points (Fig.2), respectively. The $z_{\min }$ on each beach is slightly different in this study due to the various geological settings, but they are all near the $0 \mathrm{~m}$ elevation in Yellow Sea Datum

1985. Profile volume changes per unit meter width are calculated for every survey relative to the first survey during the 2019 typhoon season. Meanwhile, we used the Inverse Distance Weight Interpolation method (Shepard, 1968) to generate digital elevation models from all the beach profiles of each survey, and the interpolation was carried out on a regular grid with an alongshore and cross-shore mesh size of $5 \mathrm{~m}$ and 

pattern of the three beaches.

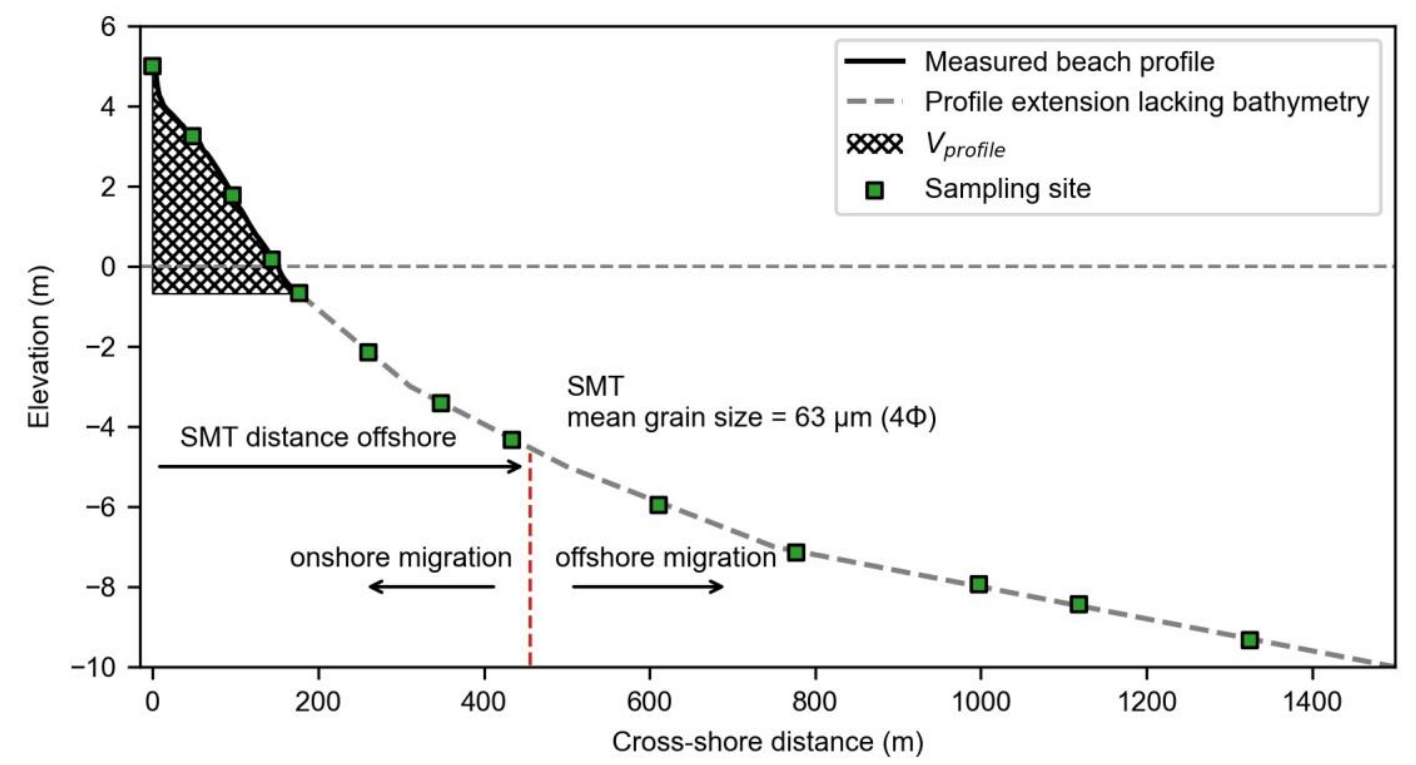

191

Fig. 2 Example of beach profile and sediment sampling sites at Dongsha beach. The black solid line shows the profile DS11 measured on August 31, 2019, while the grey dash line shows the nearshore extension of beach profile lacking nearshore bathymetry.

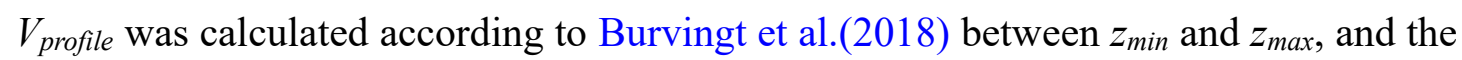
SMT was calculated according to George and Hill (2008) using grain size characteristics. Green rectangles indicate the surficial sediment sampling sites on the beach and in the nearshore.

\section{Table 1}

Number of profiles and surficial sediment samples (beach and nearshore) collected for each embayed beach during the early, middle and late stages of the 2019 typhoon season.

\begin{tabular}{ccc}
\hline Beach & Profiles & Beach (nearshore) sediment samples \\
\hline
\end{tabular}




\begin{tabular}{ccccccc}
\hline & early & middle & late & early & middle & late \\
\hline Dashali & 10 & 10 & 10 & $40(30)$ & $40(30)$ & $40(30)$ \\
Dongsha & 30 & 30 & 30 & $122(61)$ & $131(60)$ & $122(55)$ \\
Qiansha & 17 & 17 & 17 & $78(30)$ & $88(30)$ & $80(30)$ \\
\hline
\end{tabular}

\subsection{Surficial sediments}

A total of 1097 surficial sediment samples on 171 profiles were collected during the 2019 typhoon season (Table 1). Sampling sites were approximately 50-m spaced along the beach profile starting from the seawall or cliff, while spacing was increased to approximately $200 \mathrm{~m}$ in the nearshore part of the profile (Fig. 2). The sediment samples were processed according to standard laboratory procedures (Carver, 1971).

Sediment grain-size analyses were carried out by SFY-D sonic vibration type automatic sieving grain size analyzer and Malvern Mastersizer 2000 laser grain size analyzer for sand and mud samples, respectively, after desalination and separation. The graphical method (Folk and Ward, 1957) was then used to calculate the grain size parameters (Mean grain size, Skewness, Sorting coefficient and Kurtosis) of the surficial sediment. The SMT was determined according to the sediment grain size distribution characteristics, which is a boundary of sand and mud, with the mud content of $25 \%$ or the grain size of $63 \mu \mathrm{m}(4 \Phi)$ (George and Hill, 2008). SMT distance was defined as the cross-shore distance of the SMT from the landward base (seawall/cliff, the beginning

219 of each profile). The SMT migration was calculated by comparing SMT offshore distance with that measured during the first survey, with negative (positive) SMT migration corresponding to onshore (offshore) movement. 


\section{Results}

\subsection{Nearshore hydrodynamics during the typhoon season}

There were four typhoons of different classifications in the study area during the 2019 typhoon season: Tropical Storm Danas, Super Typhoon Lekima, Super Typhoon Lingling, and Typhoon Tabah. The annual average significant wave height and the mean wave period in the study area are only $0.82 \mathrm{~m}$ and $3.6 \mathrm{~s}$ (Guo et al., 2020), while the average significant wave height was $1.16 \mathrm{~m}$ during the typhoon season of 2019, with a mean wave period of $5.5 \mathrm{~s}$ (Fig. 3a \& 3b). The maximum significant wave height and wave period were $6.77 \mathrm{~m}$ and $9.9 \mathrm{~s}$, respectively. Throughout the 2019 typhoon season, waves in the study area were mainly from the southeast, with the maximum significant wave heights mainly from the directions between northeast and southeast (Fig. 3c). respect to Yellow Sea Datum 1985 in the study area from July 1 to September 30 in typhoons were from southeast, while it was from east during the last typhoon. These four typhoons all caused strong storm waves, with the maximum significant wave 
corresponding storm peak wave directions were $135^{\circ}, 40^{\circ}, 100^{\circ}$, and $84^{\circ}$, respectively.
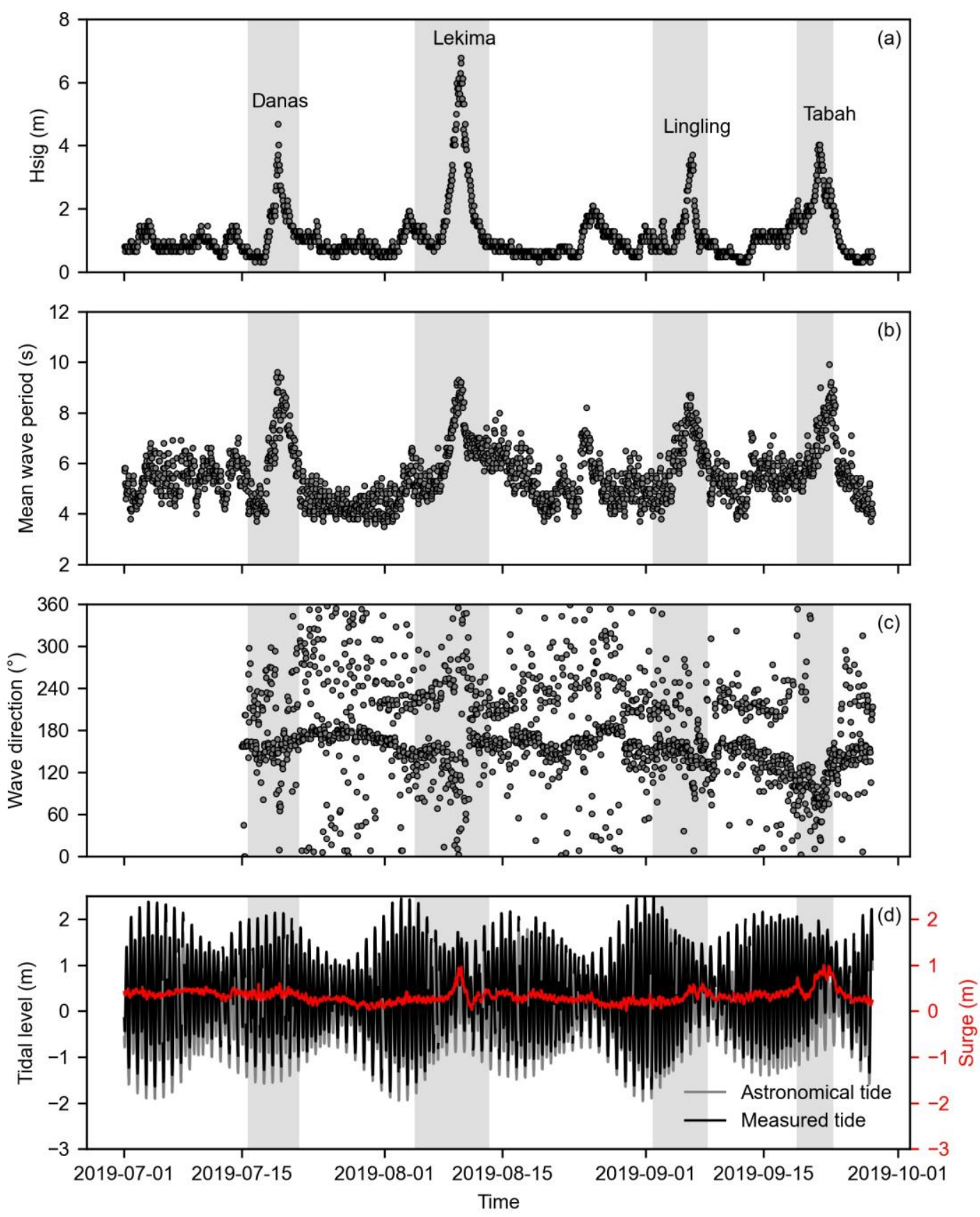

247 Fig. 3 Significant wave height (a), mean wave period (b), wave direction (c), and tidal

level and surge (d) in the nearshore of Zhujiajian Island during the 2019 typhoon season.

249 The wave directions from July 1 to July 15 in 2019 were not displayed in this figure due to the instrument failure. Measured tide, astronomical tide and surge level are with 

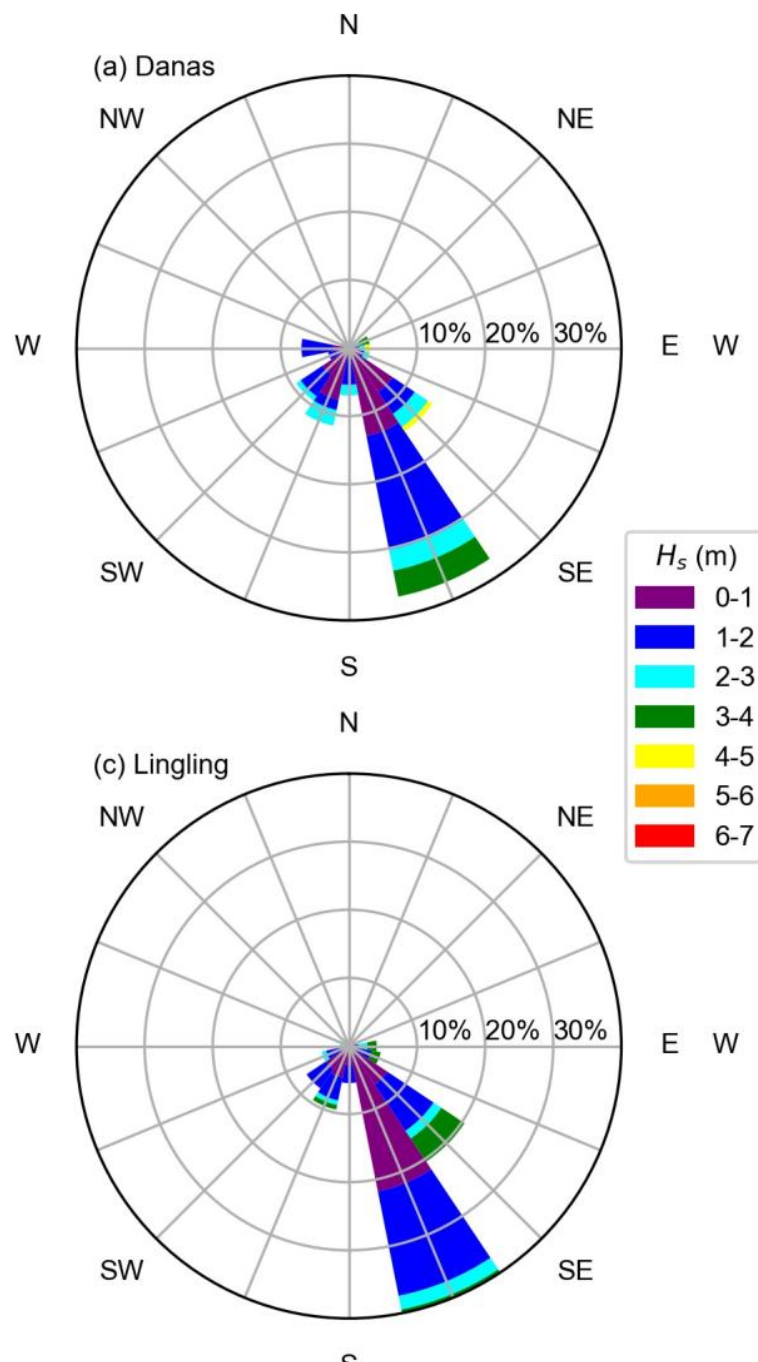

S
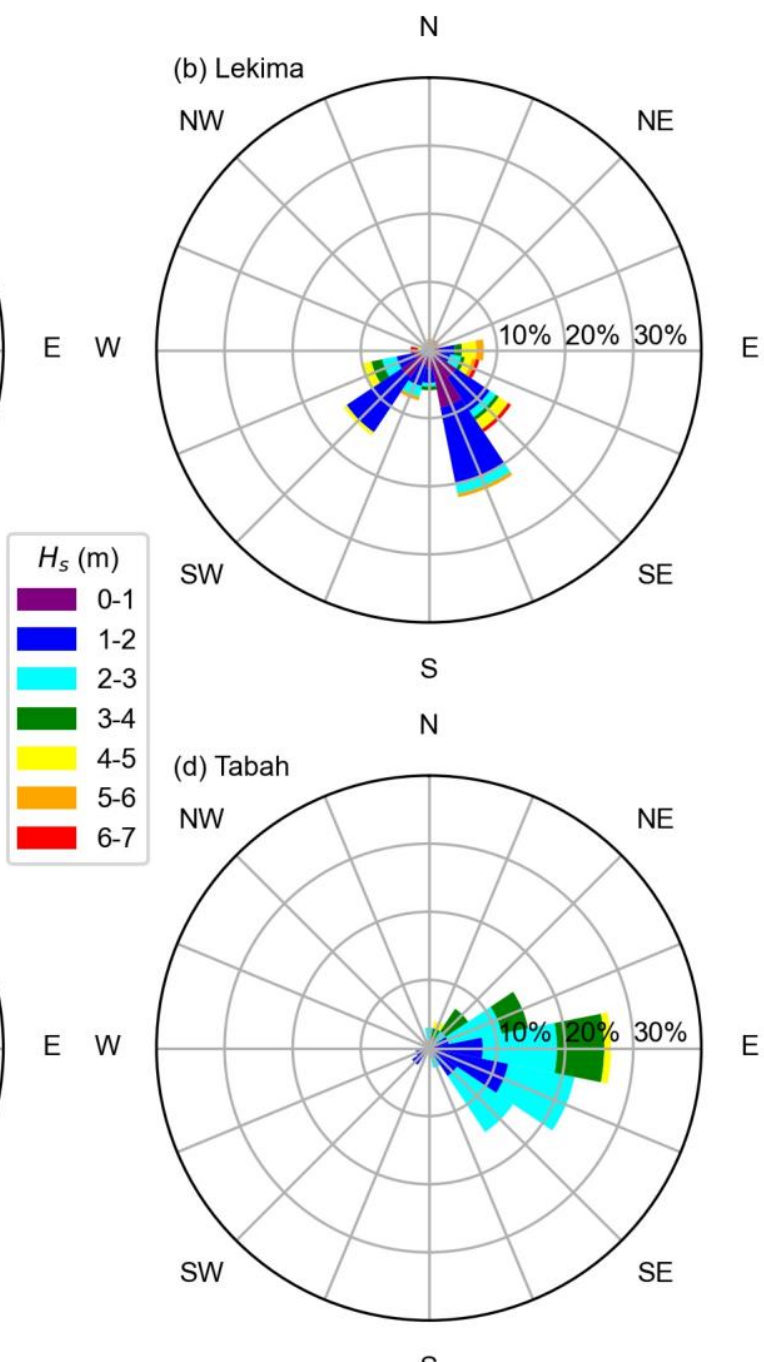

254 Fig. 4 Wave roses of Tropical Storm Danas (a), Super Typhoon Lekima (b), Super

255 Typhoon Lingling (c) and Typhoon Tabah (d). $H_{s}$ is the significant wave height.

\subsection{Beach morphological changes}

The beach profiles of Dashali show a slight accretion during the typhoon season.

The alongshore-averaged $V_{\text {profile }}$ changes in the early-middle stage, middle-late stage and the entire typhoon season were $4.57 \mathrm{~m}^{3} / \mathrm{m}, 7.35 \mathrm{~m}^{3} / \mathrm{m}, 11.92 \mathrm{~m}^{3} / \mathrm{m}$, respectively. At 
the early stage of the typhoon season, Dashali beach exhibited a berm located 40-60 m

261 from the seawall. Then, the beach berm was smoothed out by the end of typhoon season.

Overall, the profiles became smoother and more gently (Fig. 5a-e).

The alongshore-averaged $V_{\text {profile }}$ changes of Dongsha beach during the entire typhoon season is $-54.34 \mathrm{~m}^{3} / \mathrm{m}$, with the beach suffering more erosion during the early stage of the typhoon season $\left(-35.68 \mathrm{~m}^{3} / \mathrm{m}\right)$. The southern profiles (Fig. $\left.5 \mathrm{f}-\mathrm{h}\right)$ show the most dramatic change, with erosion during the entire typhoon season reaching -124.17 $\mathrm{m}^{3} / \mathrm{m}$ (profile DS11). Profiles DS05 and DS17 had berm at the early stage of the typhoon season, while the berm systems disappeared by the end of the typhoon season. Compared with the southern part of the beach, the three northern profiles (DS22, DS26, and DS30) were relatively stable during the typhoon season, with an average erosion of $-10.83 \mathrm{~m}^{3} / \mathrm{m}$.

The profiles of Qiansha beach showed an alongshore-averaged $V_{\text {profile }}$ change of $0.7 \mathrm{~m}^{3} / \mathrm{m}$ (early - middle) and $-34.65 \mathrm{~m}^{3} / \mathrm{m}$ (middle - late), respectively. The beach was the only of the three beaches that did not exhibit a berm at the start of the 2019 typhoon season. The profile shape did not substantially change, with the profiles essentially lowering during the middle-late stage. 

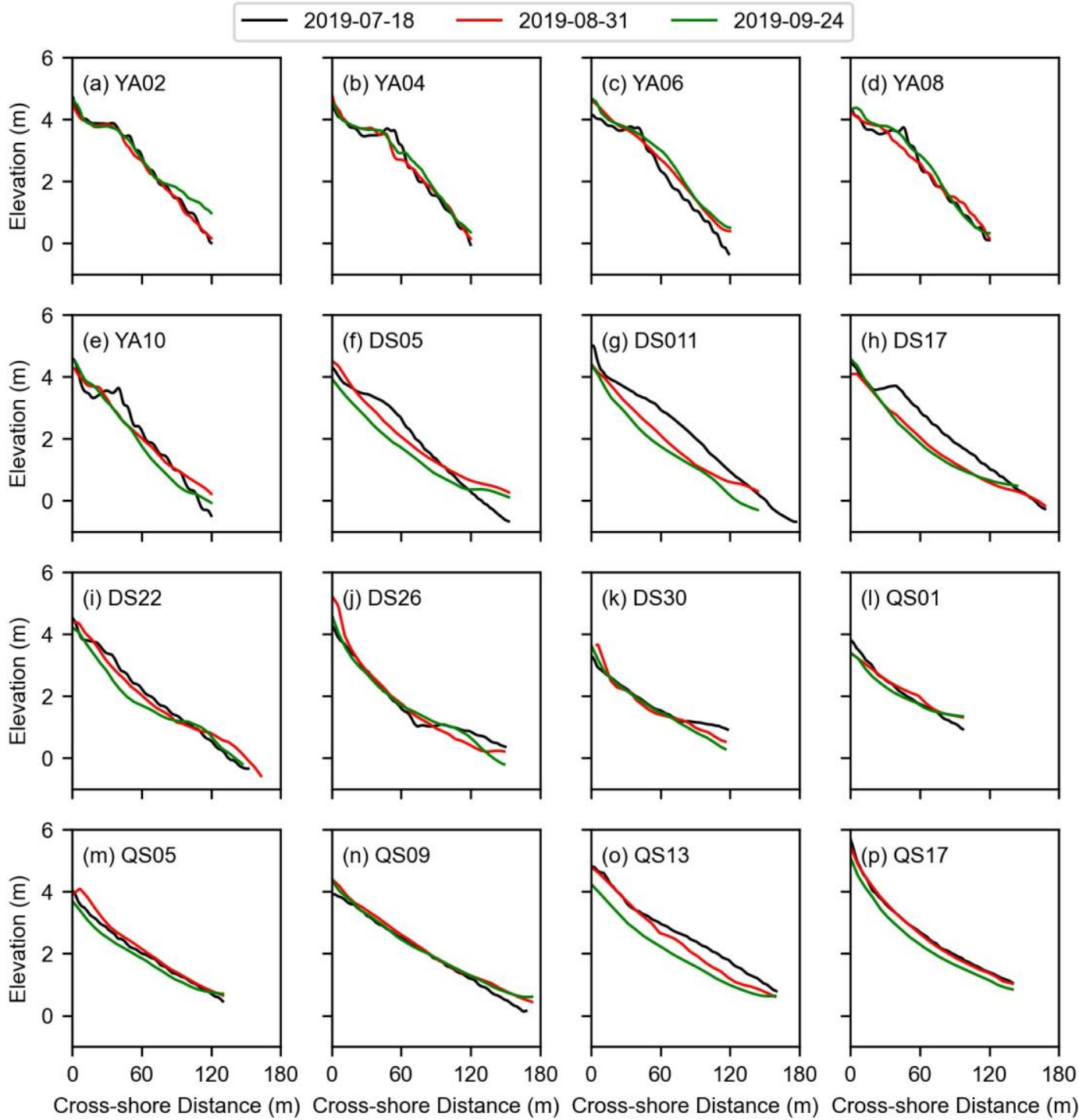

Fig. 5 Variations in typical profiles of Dashali beach (a-e), Dongsha beach (f-k) and

279 Qiansha beach (1-p) during typhoon season. Elevation is with respect to Yellow Sea

Datum 1985 in all panels.

\subsection{Beach accretion/erosion distribution patterns}

The topographic data of Dashali beach during the 2019 typhoon season shows little

$(<0.03 \mathrm{~m})$ vertical elevation change, while the minimum and maximum vertical changes locally reached $-2.45 \mathrm{~m}$ and $2.37 \mathrm{~m}$, respectively. The total beach volume 
during the typhoon season showed a slight accretion $\left(1923.22 \mathrm{~m}^{3}\right)$, with a small

accretion $\left(2188.55 \mathrm{~m}^{3}\right)$ from early stage to middle stage, and a near-stable situation ($263.64 \mathrm{~m}^{3}$ ) in the late stage. In terms of spatial variations, the southern Dashali beach was more stable than the northern part, as the largest erosion occurred in its northern part (Fig. 6a-c), which is the signature of a slight counter-clockwise beach rotation.

Dongsha beach suffered erosion throughout the typhoon season, with maximum vertical erosion reaching $-1.62 \mathrm{~m}$. At the late stage of the typhoon season, the total beach volume decreased significantly $\left(-62,466.75 \mathrm{~m}^{3}\right)$. Compared with the two other beaches, the data shows the largest morphological changes. Erosion patterns show a large alongshore variability, with large erosion of the upper beach in the southern part of the embayment, while the northern part was relatively stable, corresponding to a clockwise beach rotation (Fig. 6d-f). Interestingly, the upper beach change patterns were mirrored in the lower beach change patterns.

Qiansha beach also showed continuous erosion during the typhoon season, and beach erosion was more severe at the early stage of the typhoon season, with a total volume change of $-20,019.96 \mathrm{~m}^{3}$ throughout the 2019 typhoon season. The erosion/accretion pattern at Qiansha beach was the most uniform alongshore among the three beaches, with erosion of the upper beach and slight accretion of the lower beach suggesting a dominant offshore sand transport (Fig. 6g-i).

To sum up, the three embayed beaches showed contrasting morphological responses. The southern part of Dongsha beach showed the largest changes, and Dashali beach was the most stable. The three beaches all showed erosion on the upper part of 

transport during typhoon season.
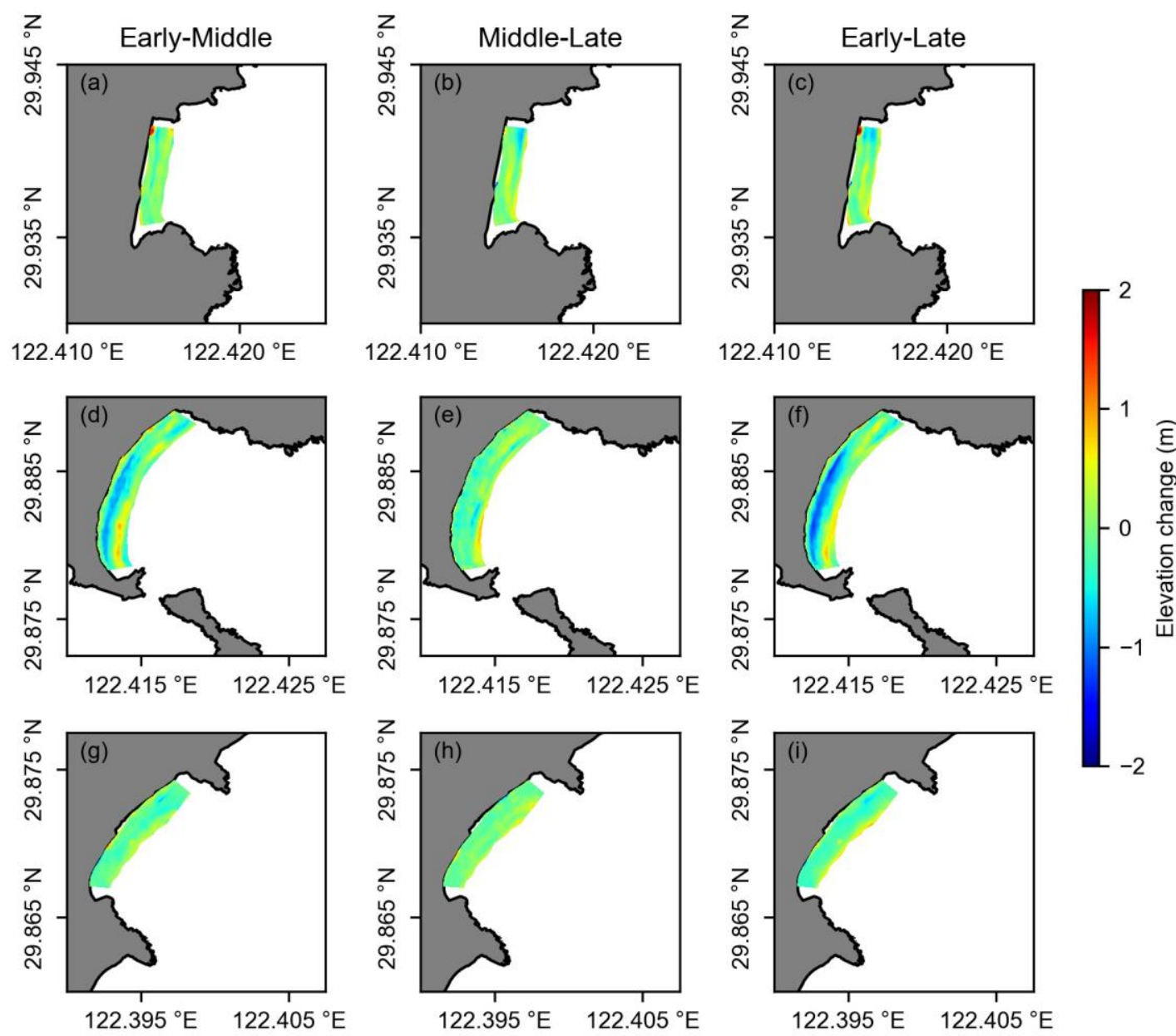

310 Fig. 6 Topographic difference plot of Dashali beach (a-c), Dongsha beach (d-f) and

311 Qiansha beach (g-i) during the typhoon season. The first, second and third columns

312 show changes during the period between early and middle stage, the period between

313 middle and late stage and the entire typhoon season, respectively.

\subsection{Variations of beach sediment characteristics}

Sediment grain size analysis shows that the sediment of the three beaches is 
size varied throughout the typhoon season, with sediment generally coarsening and characterized by increasing sorting.

Dashali beach sediment is mostly composed of fine sand, with a small amount of very-fine sand and coarse sand. At the early, middle and late stages of the typhoon season, the mean sediment grain size was $2.49 \Phi$ (ranging between $1.86 \Phi$ and $2.68 \Phi$, Fig. 7a), $2.5 \Phi$ (ranging between $1.71 \Phi$ and $2.67 \Phi$, Fig. $7 b$ ) and $2.42 \Phi$ (ranging between $1.5 \Phi$ and $2.69 \Phi$, Fig. 7c), respectively. The grain size distribution was relatively uniform with a slight change during typhoon season seemingly related to beach morphological changes. The average sediment sorting coefficients of Dashali beach increased throughout the typhoon season, that is, $0.33,0.36$, and 0.49 in the three subsequent stages of the typhoon season (Fig. 8a-c).

In addition to the fine sand components, there was a small amount of very-fine sand, coarse sand and gravel components in the surficial sediments on Dongsha beach, with almost no mud components. The sediment in the southern part of the beach was the coarsest and contained gravel. At the early stage of the 2019 typhoon season, the mean beach sediment grain size was $2.29 \Phi$ (ranging between $-1.17 \Phi$ and 3.16 $\Phi$, Fig. 7d). After two typhoons, the mean grain size was $2.37 \Phi$ (ranging between $-0.12 \Phi$ and 3.05 $\Phi$, Fig. 7e), and there was still a small amount of fine-grained gravel in southern beach. At the end of the typhoon season, the mean sediment grain size was $2.07 \Phi$ (range between $-1.08 \Phi$ and $2.96 \Phi$, Fig. 7f), with some coarse-grained gravels appearing in the southern part of the beach, where grain size characteristics were the most variable throughout the typhoon season. The sorting coefficient became worse at 
340 the worst at Dongsha beach.

Qiansha beach sediments were primarily fine sand, with a small amount of very-

342 fine sand and coarse sand. At the early stage of the typhoon season, the mean grain size

343 of the surficial sediments on the beach was $2.61 \Phi$ (ranging between $1.63 \Phi$ and $3.1 \Phi$,

344 Fig. $7 \mathrm{~g}$ ). By the middle stage, the mean grain size slightly decreased to $2.64 \Phi$ (ranging

345 between $2.25 \Phi$ and $2.74 \Phi$, Fig. $7 \mathrm{~h}$ ). At the end of the typhoon season, the mean grain

346 size was $2.67 \Phi$ (ranging between $2.39 \Phi$ and $2.78 \Phi$, Fig. 7i). The sediment grain size

347 at Qiansha beach was the most uniform spatially and the finest. The sediment

348 characteristics showed the smallest change of the three beaches during the typhoon

349 season, and the sorting was the best (sorting coefficient ranging between 0.26 and 0.3 ,

$350 \quad$ Fig. 8g-i). 

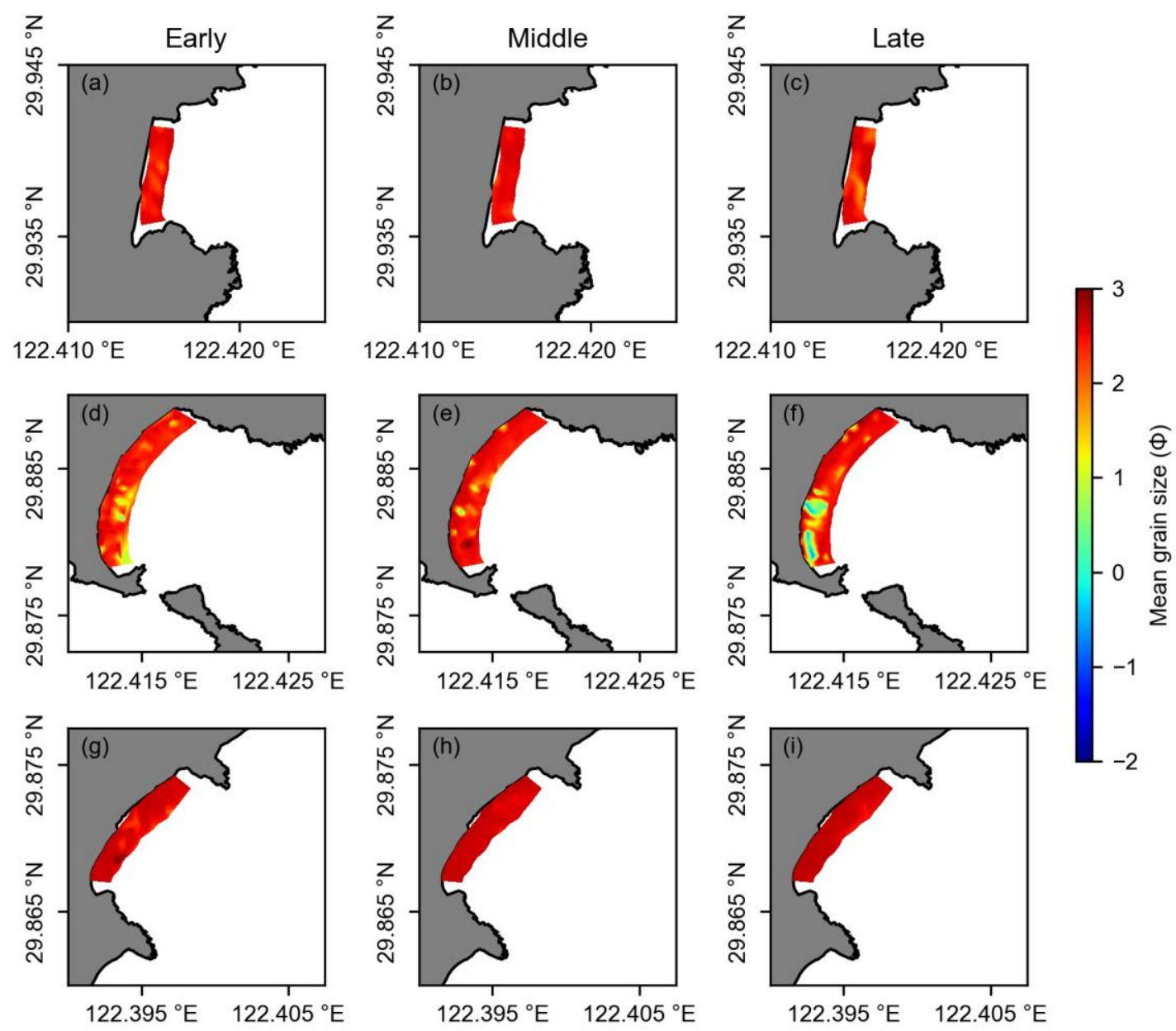

352 Fig. 7 Maps of mean surficial sediment grain sizes on Dashali (a-c), Dongsha (d-f) and

Qiansha (g-i) during the early, middle and late stages of typhoon season. 

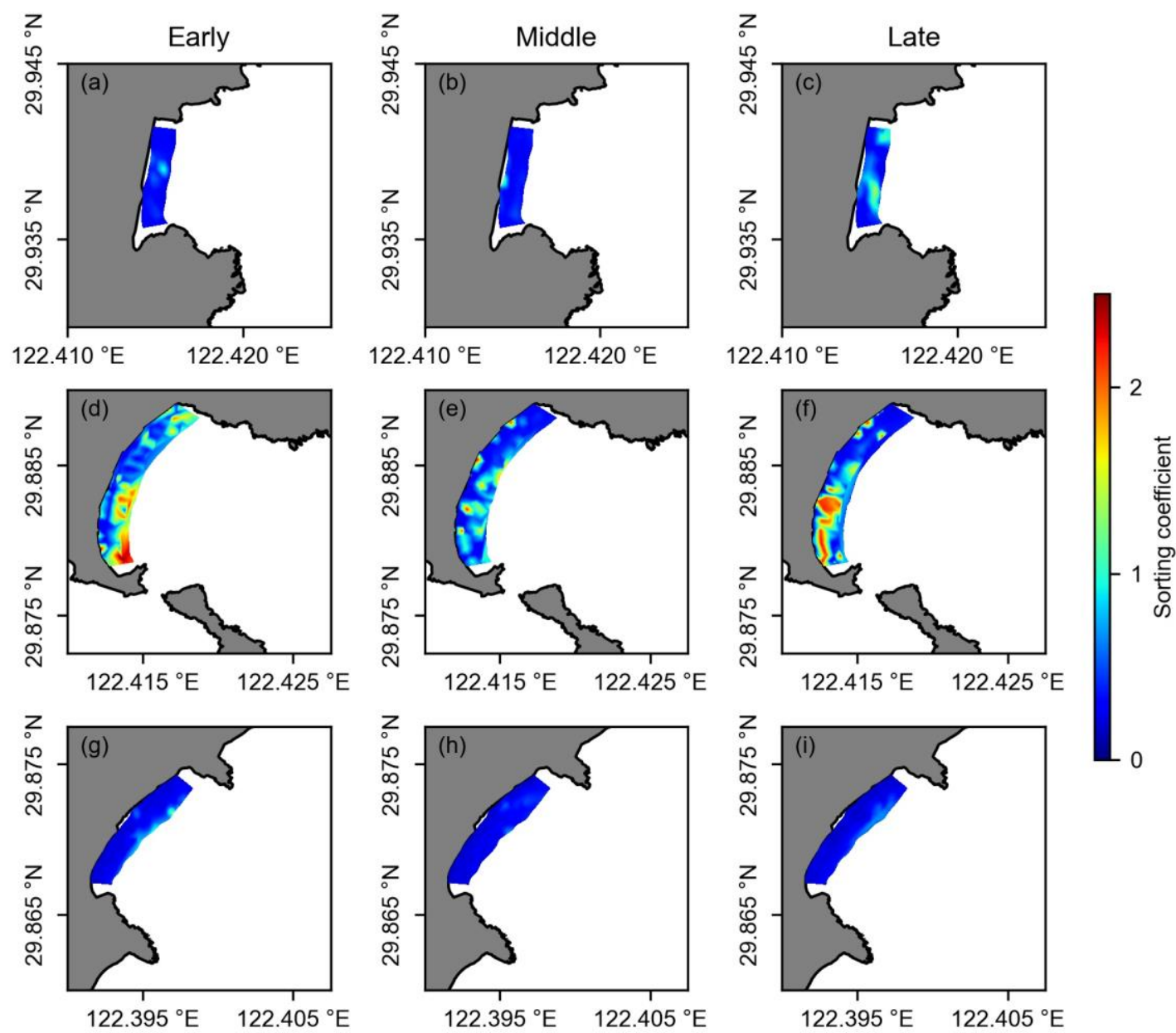

356 Fig. 8 Sorting coefficients of beach surficial sediments on Dashali (a-c), Dongsha (d-f) and Qiansha (g-i) during the early, middle and late stages of typhoon season.

\subsection{Location and migration of SMTs}

Most of the surficial sediments in the nearshore of Dashali, Dongsha, and Qiansha

were muddy sediments, with a dominant seaward fining trend. The nearshore surficial

sediments of Dongsha showed the coarsest grain size among the three beaches, while

that of Qiansha showed the finest grain size (Table 2). The nearshore surficial sediments all coarsened during the 2019 typhoon season, among which the nearshore sediments at Qiansha were the most stable. Compared with the beach sediments (Table S1), the 
nearshore sediments showed little changes during typhoon season, with small variations in sorting coefficient $(\sigma)$, skewness $\left(S_{k}\right)$ and kurtosis $\left(K_{g}\right)$.

Table 2

Grain size characteristics of nearshore surficial sediments during the 2019 typhoon

season.

\begin{tabular}{ccccccc}
\hline \multirow{2}{*}{ Location } & Sampling Date & $\begin{array}{c}D_{50} \\
(\Phi)\end{array}$ & $\begin{array}{c}M_{z} \\
(\Phi)\end{array}$ & $\sigma$ & $S_{k}$ & $K_{g}$ \\
\hline Dashali nearshore & $2019 / 07 / 18$ & 7.32 & 7.47 & 1.36 & 0.17 & 1.02 \\
& $2019 / 08 / 31$ & 6.65 & 6.8 & 1.46 & 0.13 & 1.02 \\
& $2019 / 09 / 24$ & 6.38 & 6.5 & 1.46 & 0.08 & 1.06 \\
Dongsha nearshore & $2019 / 07 / 18$ & 6.88 & 7 & 1.41 & 0.10 & 1.12 \\
& $2019 / 08 / 31$ & 5.78 & 5.96 & 1.38 & 0.13 & 1.01 \\
Qiansha nearshore & $2019 / 09 / 24$ & 5.47 & 5.54 & 1.48 & 0.06 & 1.53 \\
& $2019 / 07 / 18$ & 7.74 & 7.72 & 1.48 & 0.08 & 1.03 \\
& $2019 / 08 / 31$ & 7.02 & 7.13 & 1.38 & 0.11 & 0.96 \\
& $2019 / 09 / 24$ & 7.13 & 7.2 & 1.37 & 0.01 & 1.12 \\
\hline
\end{tabular}

By calculating the mean grain size $\left(M_{z}\right)$ and mud content of the beach and nearshore surficial sediments, the results show that the average SMT offshore distances typhoon season were $201 \mathrm{~m}, 442 \mathrm{~m}$, and $326 \mathrm{~m}$ (Fig. 9), respectively. Their headland extents are $600 \mathrm{~m}, 1350 \mathrm{~m}$, and $800 \mathrm{~m}$, respectively, suggesting that the longer the

377 headland extent, the farther offshore the SMT, which will be discussed in the next section. Dongsha beach, with the coarsest sediment grain size, has the farthest SMT distance from base. Under the high-energy typhoon season, the SMTs at the three beaches were stable or migrated seaward. 

approximately $7 \mathrm{~m}$, resulting in a near-zero net migration. The SMT migration was uniform alongshore. In contrast, the Dongsha beach SMT showed continuous seaward migration at all profiles and together with coarsening sediment. Among the three beaches, the SMT of Dongsha beach had the largest migration during the typhoon season with also substantial alongshore variability. The SMT of the southern Dongsha beach (DS05, DS11, DS17) migrated seawards by the largest amount (170 m, Fig. 9b), while the SMT in the northern part was relatively stable, with SMT migration ranging between $-5 \mathrm{~m}$ and $16 \mathrm{~m}$. The SMT of Qiansha migrated offshore by $17.6 \mathrm{~m}$ during the early stage of the season before migrating shoreward by $13.6 \mathrm{~m}$ (Fig. 9c). During the entire typhoon season, the SMT of Qiansha moved by only $4 \mathrm{~m}$.
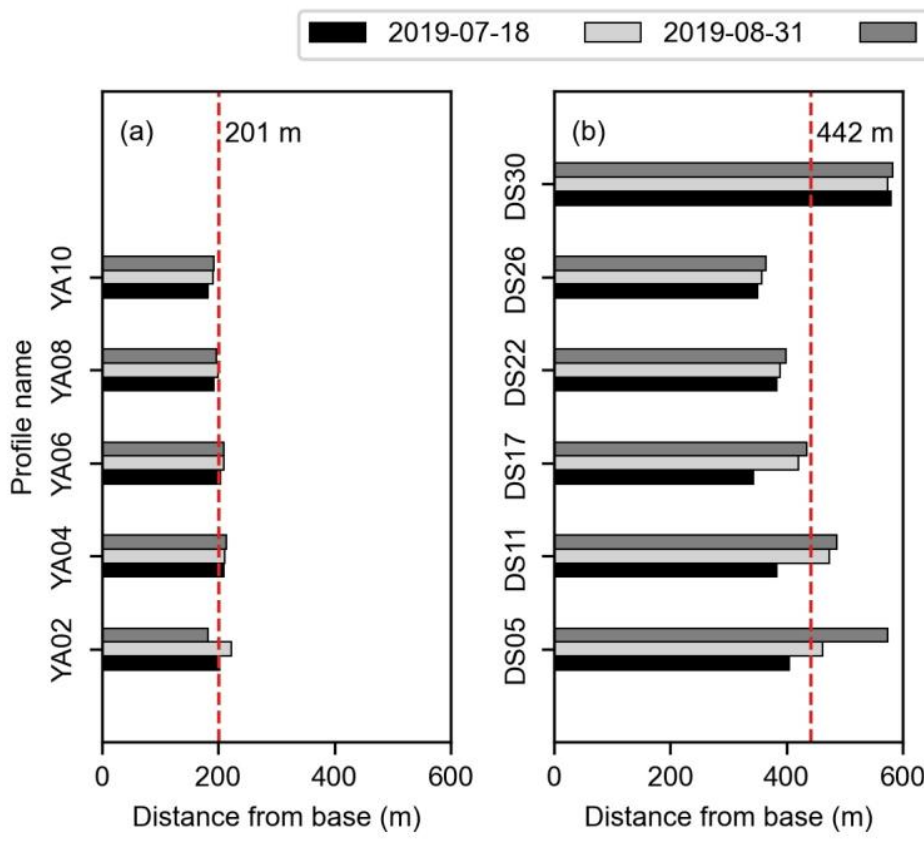
2019-09-24

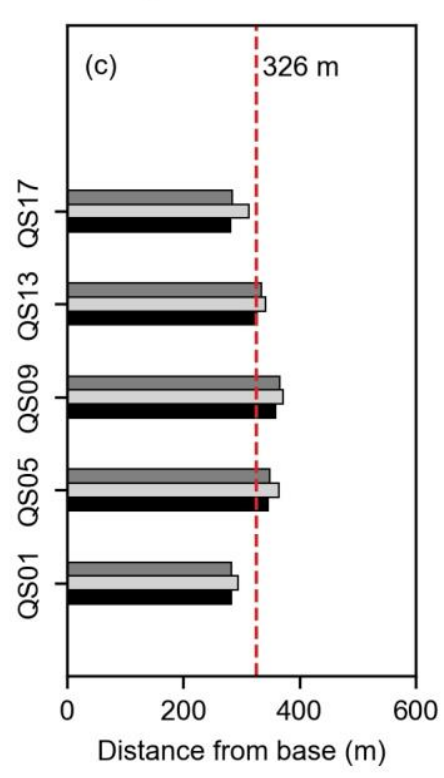

394 Fig. 9 SMT offshore distances at Dashali (a), Dongsha (b), and Qiansha (c) at the early (18/7/2019), middle (31/8/2019) and late (24/9/2019) stages of the 2019 typhoon season. 
typhoon season.

\section{Discussion}

\subsection{Factors affecting SMT location}

SMT is an important morphological feature of beaches, and its location depends on hydrodynamic settings (mainly waves and tides), sediment supply and potential human interventions. Previous works indicate that the stronger the wave forcing, the farther SMT extends offshore (Dunbar and Barrett, 2005; George and Hill, 2008), and the coarser beach sediment grain size (Friedman, 1979). This is confirmed here, with Dongsha beach showing the most offshore SMT of the three beaches in Zhujiajian Island (Fig. 9). We also compared the SMT results of the three beaches in this study with 12 other embayed beaches along the east coast of China, for a total of 15 embayed beaches, showing the same relationship (Fig. 10a, Table 3). Tides affect coastal currents and, in turn, sediment transport, beach morphology and SMT location. This is further illustrated when plotting SMT against tidal range, by including the same 12 embayed beaches to our dataset (Fig. 10b and Table 3). In line with Zhao et al. (2020b), the SMT offshore distance at embayed beaches decreases with increasing tidal range. The three embayed beaches in this study have the same mean spring tidal range $(2.6 \mathrm{~m})$ and similar nearshore significant wave height, but show different SMT locations (Fig. 10), indicating that tide and significant wave height are not the only influencing factors. Headland configuration (shape, distance, offshore extent) at embayed beaches can also remarkably affect nearshore currents and sediment transport (Short and Masselink, 
1999) as well as shoreline response and embayment plane-shape (Castelle et al., 2020).

419 Intense rip currents flowing against the headlands can also occur under storm waves 420 and potentially transport large amount of beach sediment seawards (Mouragues et al.,

421 2020; Valiente et al., 2019). Fig. 10c and Table 3 show that SMT offshore distance 422 increases with increasing headland extent at embayed beaches along the east coast of 423 China. Larger headland may promote offshore sand transport and, therefore, more 424 offshore SMT. Wave exposure (embayment orientation) is another important parameter 425 affecting nearshore currents and sediment pathways. Besides, small differences in the inner shelf slope can transform waves differently (Dillenburg et al., 2000; Schwab et al., 2000), which may further contribute to the differences of SMT position between the three beaches. Further work, including more data and process-based modelling, will be required to verify these relationships and further explain the influence of tide, wave height, headland extent, wave exposure and inner shelf slope on SMT.

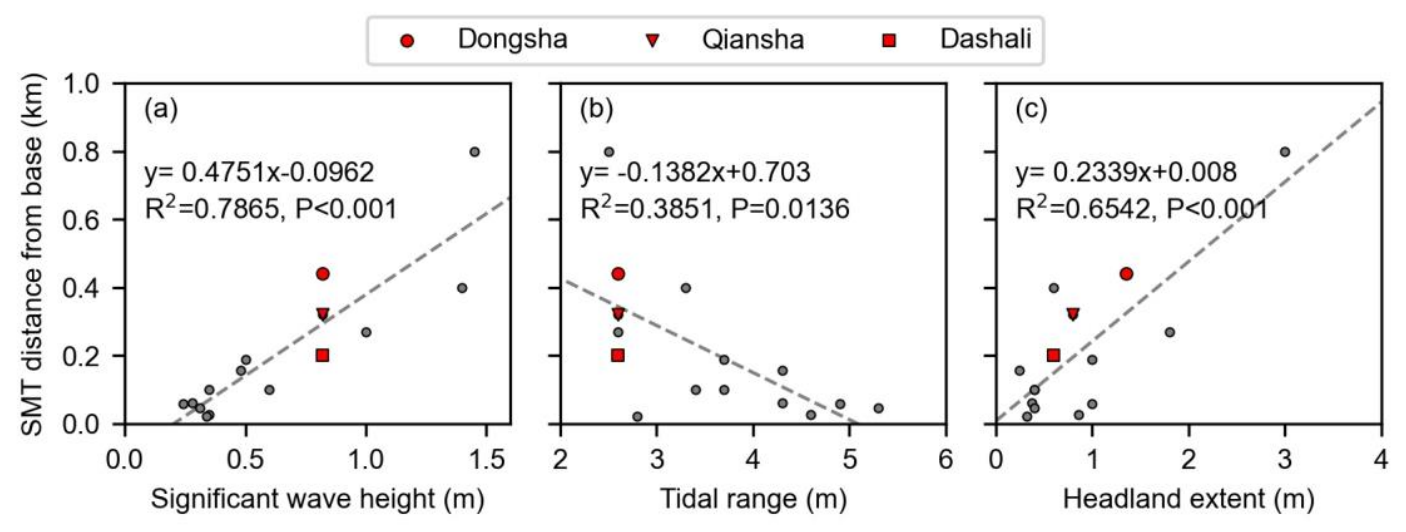

432 Fig. 10 SMT distance from base against significant wave height (a), tide range (b) and

433 headland extent (c) of embayed beaches in eastern China (refer to Table 3). In all panels

434 the solid lines show the best linear regression and corresponding statistics. The red symbols show the three beaches in this study, in which the rectangular, circle and 
triangular represent Dashali, Dongsha, and Qiansha, respectively.

Table 3

438 SMT distance, morphological and hydrodynamic parameters of embayed beaches in

439 eastern China in references and this study.

\begin{tabular}{ccccccc}
\hline & $\begin{array}{c}\text { Headla } \\
\text { nd } \\
\text { extent } \\
(\mathrm{km})\end{array}$ & $\begin{array}{c}\text { Beach } \\
\text { length } \\
(\mathrm{km})\end{array}$ & $\begin{array}{c}\text { SMT } \\
\text { Dist. } \\
(\mathrm{km})\end{array}$ & $\begin{array}{c}H_{\text {sig }} \\
(\mathrm{m})\end{array}$ & $\begin{array}{c}\text { Tidal } \\
\text { range } \\
(\mathrm{m})\end{array}$ & References \\
\hline Beach & 3.0 & 4.8 & 0.8 & 1.45 & 2.5 & Yu et al., 2016 \\
Xishu & 0.4 & 0.45 & 0.1 & 0.60 & 3.4 & Duan, 2015 \\
Dongsha & 1.35 & 1.5 & 0.44 & 0.82 & 2.6 & This study \\
Qiansha & 0.8 & 1.2 & 0.32 & 0.82 & 2.6 & This study \\
Dashali & 0.6 & 0.9 & 0.2 & 0.82 & 2.6 & This study \\
Nansha & 1.8 & 1.1 & 0.27 & 1.0 & 2.6 & Huang et al.(2016) \\
Huangcheng & 1.0 & 1.8 & 0.19 & 0.5 & 3.7 & Huang et al.(2016) \\
Xiasha & 0.4 & 0.6 & 0.1 & 0.35 & 3.7 & Huang et al.(2016) \\
Jihu & 0.6 & 1.25 & 0.4 & 1.4 & 3.3 & Huang et al.(2016) \\
Guhu & 0.24 & 0.38 & 0.158 & 0.48 & 4.3 & Zhao et al.(2020b) \\
Zuokeng & 0.375 & 0.64 & 0.062 & 0.28 & 4.3 & Zhou et al.(2019) \\
Jiangyin east & 0.4 & 0.91 & 0.047 & 0.31 & 5.3 & Zhao et al.(2020b) \\
Quangang Wuli & 0.86 & 1.43 & 0.026 & 0.35 & 4.6 & Zhao et al.(2020b) \\
Lieyu & 0.32 & 1.65 & 0.021 & 0.34 & 2.8 & Zhao et al.(2020b) \\
Nantaiwu & 1.0 & 1.73 & 0.06 & 0.24 & 4.9 & Zhou et al.(2019) \\
\hline
\end{tabular}

Note: SMT Dist. is the SMT distance from the base on each beach. $H_{\text {sig }}$ is the annual average

441 significant wave height of the nearshore.

\subsection{SMT migration response during typhoon season}

Just like beach response, it is critical to better understand SMT response to typhoons. Our results show that SMT migration during the typhoon season is correlated

445 with beach response (Fig. 11). Generally, SMT offshore migration increases with 446 increasing beach erosion. The correlation between SMT migration and beach volumetric change is observed and statistically significant, but mostly during the early 
period of the typhoon season. An explanation can be that the disequilibrium between

$449 \mathrm{SMT} /$ beach volume and the incident wave energy is maximized during the start of the

450 typhoon season under high-energy conditions, which results in maximized response and

451 clear SMT/beach volume change patterns. During the rest of the typhoon season,

452 disequilibrium between beach/SMT system and incident wave energy is minimized

453 resulting in more site-specific response, and weaker correlation. More measurements

454 of SMT migration at more embayed beaches are required to perform a robust statistical

455 analysis, which was based only on three beaches herein. Besides, Cheng et al.(2014)

456 found that the SMT at Dongsha beach is approximately $430 \mathrm{~m}$ from the seawall under

457 the calm wave condition, while the SMT was located $442 \mathrm{~m}$ offshore from the seawall

458 during the 2019 typhoon season. This is in line with our observation of an offshore SMT

459 migration together with beach erosion during the typhoon season. SMT elevation

460 change was not addressed here, due to the absence of nearshore bathymetry, which will

461 need further investigation.

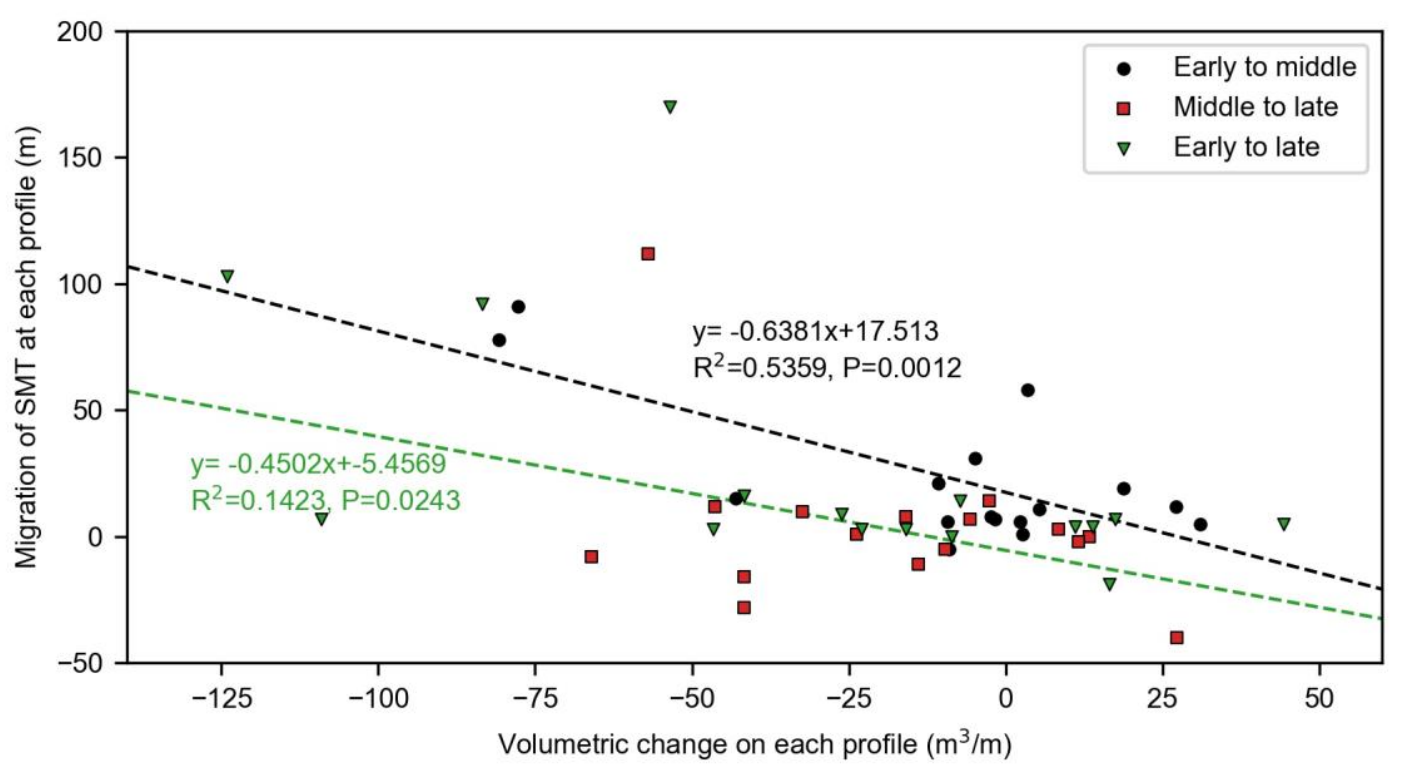

463 Fig. 11 Volumetric change on each profile ( $\left.V_{\text {profile }}\right)$ against SMT migration at each 
profile of the three embayed beaches during the 2019 typhoon season. There is no significant correlation between the volumetric change and SMT migration during the period between the middle and late stages of the typhoon season (red rectangles).

Human activities such as the construction of seawalls and beach nourishments may also affect the migration of SMT. Dongsha beach has seawalls causing continuous erosion on the beach (Cheng et al., 2014; Guo et al., 2018), thus such promoted offshore sediment transport may further lead to a seaward SMT migration. Besides, nourishment projects were implemented on Dongsha beach from 2016 to 2017, with the borrowed sediments mainly placed in the southern end of the beach (Guo et al., 2020). The borrowed sediments are not "native" beach sediments and can be easily transported away from the nourishment area (Seymour et al., 2005). This may have modified SMT in the south of Dongsha beach. Compared with Dongsha beach, the SMTs of Dashali and Qiansha were relatively stable during typhoon season. These two beaches are more natural than Dongsha, suggesting that SMTs of beaches with less human intervention are more stable. In addition, SMTs of embayed beaches are known to be more stable than estuarine beaches (Zhao et al., 2020b), which is confirmed in this study with overall small SMT migrations.

Embayed beach exposure to incident storm wave conditions is important to beach response during typhoon seasons (Qi et al., 2010), which may also affect the migration of SMTs. The beach orientations of Dashali, Dongsha and Qiansha are $3^{\circ}, 19^{\circ}$ and $40^{\circ}$ (Fig. 1), respectively, while the main storm wave directions of the four typhoons are from southeast and east (Fig. 4). The Super typhoon Lekima with maximum $H_{s}$ 
approaching $6.77 \mathrm{~m}$ in the early stage of the typhoon season may result in the biggest impact, and the angle between the main storm direction and the orientations of Dongsha and Qiansha are close to shore normal. Therefore, Dongsha and Qiansha eroded significantly during the early-middle stage of typhoon season, which corresponds to the offshore migration of SMTs on these two beaches.

Sediment supply is also an important factor affecting the SMT distribution and migration (Anthony et al., 2002; Anthony and Dolique, 2004; Chang et al., 2017; George and Hill, 2008; Zhao et al., 2020a). The southward transport of fine-grained sediments from the Yangtze River Estuary driven by coastal currents makes the adjacent sea waters of the Zhoushan Archipelago rich in fine-grained sediments (Hu et al., 2009; Li et al., 2018). Cheng et al.(2014) found that there is a SMT in the nearshore of Dongsha beach in approximately $5 \mathrm{~m}$ depth (about $430 \mathrm{~m}$ from the seawall) with seasonal changes in flood and dry seasons. Dashali and Qiansha have a similar sedimentary environment with Dongsha affected by the fluvial sediments from Yangtze River Estuary, thus the SMTs on these two beaches may also exhibit seasonal changes.

\section{Conclusions}

This study focuses on the location, migration and influencing factors of the SMTs on the embayed sandy beaches of Dashali, Dongsha and Qiansha, east coast of Zhujiajian Island. Beach topographies and surficial sediment characteristics were acquired during the early, middle and late stages of the 2019 typhoon season. During this typhoon season, the beaches showed large and variable morphological changes driven by the high-energy wave forcing. Only Dashali beach showed no net volume 
change, while Donghsa and Qiansha severely and moderately eroded, respectively.

Despite different volumetric changes, all three beaches showed similar profile evolution with berm smoothing and more gently sloping shape, reflecting net offshore sediment transport. Beach sediments coarsened at the three sites with worse sorting performance during the typhoon season, with the nearshore surficial sediments showing similar changes. The SMTs of the three beaches were stable or migrated offshore during the typhoon season. Including data from 12 other embayed beaches in eastern China, the SMT distance offshore was found to positively correlate with significant wave height and headland offshore extent, and negatively with beach volume change and tidal range. This research can provide a reference for beach management and sustainable beach development on such embayed beaches in the world.

\section{Acknowledgements}

This study was supported by the Public Science and Technology Research Funds Projects of Ocean, China (NO. 201405037) and the joint PhD program of the China Scholarship Council for Overseas Studies (NO. 202006140106). The authors thank Zuyin Jiang and Min Zhang for their help in field work, the National Meteorological Center of China for the open-source typhoon data and Google Earth for the open-source remote sensing data. We also thank the editor and reviewers for their insightful and constructive comments.

\section{Declaration of interest}


The authors declare that they have no known competing financial interests or personal relationships that could have appeared to influence the work reported in this paper.

\section{Data Availability}

534

More typhoon data can be obtained from the National Meteorological Center of China

(http://typhoon.nmc.cn). Tidal data are provided by Shenjiamen Marine Station. Wave data, topographic data and sediment data are available upon request by contacting the corresponding author (slchen@sklec.ecnu.edu.cn).

\section{References}

Anthony, E.J., Dolique, F., 2004. The influence of Amazon-derived mud banks on the morphology of sandy headland-bound beaches in Cayenne, French Guiana: a short- to long-term perspective. Mar. Geol. 208, 249-264. https://doi.org/10.1016/j.margeo.2004.04.011

Anthony, E.J., Gardel, A., Dolique, F., Guiral, D., 2002. Short-term changes in the plan shape of a sandy beach in response to sheltering by a nearshore mud bank, Cayenne, French Guiana. Earth Surf. Process. Landforms 27, 857-866. https://doi.org/10.1002/esp.357

Burvingt, O., Masselink, G., Scott, T., Davidson, M., Russell, P., 2018. Climate forcing of regionally-coherent extreme storm impact and recovery on embayed beaches. Mar. Geol. 401, 112-128. https://doi.org/10.1016/j.margeo.2018.04.004

Cai, F., Dean, R.G., Liu, J., 2011. Beach nourishment in China: Status and prospects, in: Coastal Engineering Proceedings.

p. 31. 
553

554

Carver RE, 1971. Procedures in sedimentary petrology. Wiley- Interscience, New York.

Castelle, B., Robinet, A., Idier, D., D’Anna, M., 2020. Modelling of embayed beach equilibrium planform and rotation signal. Geomorphology 369, 107367. https://doi.org/10.1016/j.geomorph.2020.107367

Castelle, B., Turner, I.L., Bertin, X., Tomlinson, R., 2009. Beach nourishments at Coolangatta Bay over the period 1987-2005: Impacts and lessons. Coast. Eng. 56, 940-950. https://doi.org/10.1016/j.coastaleng.2009.05.005

Chang, T.S., Hong, S.H., Chun, S.S., Choi, J.-H., 2017. Age and morphodynamics of a sandy beach fronted by a macrotidal mud flat along the west coast of Korea: a lateral headland bypass model for beach-dune formation. Geo-Marine Lett. 37, 361-371. https://doi.org/10.1007/s00367-016-0486-y

Cheng, L., Shi, L., Xia, X., Tong, X., 2014. Sedimentation and recent morphological changes at Dongsha beach, Zhujiajian Island, Zhejiang Province. Mar. Geol. Quat. Geol. 34, 37-44.

Chiva, L., Pagán, J.I., López, I., Tenza-Abril, A.J., Aragonés, L., Sánchez, I., 2018. The effects of sediment used in beach nourishment: Study case El Portet de Moraira beach.

Sci. Total

Environ.

$628-629$,

$64-73$. https://doi.org/10.1016/j.scitotenv.2018.02.042

Cooke, B.C., Jones, A.R., Goodwin, I.D., Bishop, M.J., 2012. Nourishment practices on Australian sandy beaches: A review. J. Environ. Manage. 113, 319-327. https://doi.org/10.1016/j.jenvman.2012.09.025 
Dai, Z.J., Du, J. zhou, Li, C.C., Chen, Z.S., 2007. The configuration of equilibrium beach profile in South China. Geomorphology 86, 441-454. https://doi.org/10.1016/j.geomorph.2006.09.016

Dillenburg, S.R., Roy, P.S., Cowell, P.J., Tomazelli, L.J., 2000. Influence of Antecedent Topography on Coastal Evolution as Tested by the Shoreface Translation-Barrier Model (STM). J. Coast. Res. 16, 71-81.

Duan, Y., 2015. Research on the Effect of Renovation and Restoration of Haizhou Bay Beach. Nanjing Normal University.

Dunbar, G.B., Barrett, P.J., 2005. Estimating palaeobathymetry of wave-graded continental shelves from sediment texture. Sedimentology 52, 253-269. https://doi.org/10.1111/j.1365-3091.2004.00695.x

Edwards, B.D., 2002. Variations in sediment texture on the northern Monterey Bay National Marine Sanctuary continental shelf. Mar. Geol. 181, 83-100. https://doi.org/10.1016/S0025-3227(01)00262-6

Folk, R.L., Ward, X.C., 1957. Brazos River Bar: a Study in the Significance of Grain Size Parameters. J. Sediment. Petrol.

Friedman, G., 1979. Address of the retiring President of the International Association of Sedimentologists: Differences in size distributions of populations of particles among sands of various origins. Sedimentology 26, 3-32. https://doi.org/10.1111/j.1365-3091.1979.tb00336.x

Ge, Z., Dai, Z., Pang, W., Li, S., Wei, W., Mei, X., Huang, H., Gu, J., 2017. LIDARbased detection of the post-typhoon recovery of a meso-macro-tidal beach in the 
Beibu Gulf, China. Mar. Geol. 391, 127-143.

597

598

599

600

601

602

603

604

605

606

607

608

609

610

611

612

613

614

615

616

617 https://doi.org/10.1016/j.margeo.2017.08.008

George, D.A., Hill, P.S., 2008. Wave climate, sediment supply and the depth of the sand-mud transition: A global survey. Mar. Geol. 254, 121-128. https://doi.org/10.1016/j.margeo.2008.05.005

George, D.A., Hill, P.S., Milligan, T.G., 2007. Flocculation, heavy metals (Cu, Pb, Zn) and the sand-mud transition on the Adriatic continental shelf, Italy. Cont. Shelf Res. 27, 475-488. https://doi.org/10.1016/j.csr.2005.06.013

Guo, J., Shi, L., Chen, S., Ye, Q., 2019. Response of Dongsha beach in Zhoushan to continuous storms based on Argus images. Oceanol. Limnol. Sin. 50, 728-739. https://doi.org/10.11693/hyhz20181200285

Guo, J., Shi, L., Pan, S., Ye, Q., Cheng, W., Chang, Y., Chen, S., 2020. Monitoring and evaluation of sand nourishments on an embayed beach exposed to frequent storms in eastern China. Ocean Coast. Manag. 195, 105284. https://doi.org/10.1016/j.ocecoaman.2020.105284

Guo, J., Shi, L., Tong, X., Zheng, Y., Xu, D., 2018. The response to tropical storm Nakri and the restoration of Dongsha Beach in Zhujiajian Island, Zhejiang Province. Haiyang Xuebao 40, 137-147. https://doi.org/10.3969 /j.issn.02534193.2018.09.012

Hamm, L., Capobianco, M., Dette, H.., Lechuga, A., Spanhoff, R., Stive, M.J.., 2002. A summary of European experience with shore nourishment. Coast. Eng. 47, 237264. https://doi.org/10.1016/S0378-3839(02)00127-8 
Hanson, H., Brampton, A., Capobianco, M., Dette, H.., Hamm, L., Laustrup, C., Lechuga, A., Spanhoff, R., 2002. Beach nourishment projects, practices, and objectives-a European overview. Coast. Eng. 47, 81-111. https://doi.org/10.1016/S0378-3839(02)00122-9

Hu, R., Wu, J., Li, G., Zhu, L., Ma, F., 2009. Characteristics of sediment transport in the Zhoushan Archipelago sea area. Acta Oceanol. Sin. 28, 116-127.

Huang, S., Yao, W., Liu, X., Wu, C., 2016. Profile Characteristics of the Beaches Adjacent to Muddy Seabed i n the Headland Bays. Chinese Coast. Eng. 35, 1-9. https://doi.org/10.3969/j.issn.1002-3682.2016.04.001

Hudson, C., Baily, B., 2018. Delivering sustainable coasts: Monitoring the long-term stability of a breached barrier beach, Porlock Bay, Somerset, United Kingdom. Ocean Coast. Manag. 152 , $88-99$. https://doi.org/10.1016/j.ocecoaman.2017.11.022

Kuang, C., Mao, X., Gu, J., Niu, H., Ma, Y., Yang, Y., Qiu, R., Zhang, J., 2019. Morphological processes of two artificial submerged shore-parallel sandbars for beach nourishment in a nearshore zone. Ocean Coast. Manag. 179, 104870. https://doi.org/10.1016/j.ocecoaman.2019.104870

Li, G., Gao, S., Wang, Y., Li, C., 2018. Sediment flux from the Zhoushan Archipelago, eastern China. J. Geogr. Sci. https://doi.org/10.1007/s11442-018-1479-8

Li, Y., Zhang, C., Chen, D., Zheng, J., Sun, J., Wang, P., 2021. Barred beach profile equilibrium investigated with a process-based numerical model. Cont. Shelf Res. 222, 104432. https://doi.org/10.1016/j.csr.2021.104432 
Liu, G., Cai, F., Qi, H., Zhu, J., Lei, G., Cao, H., Zheng, J., 2019. A method to nourished beach stability assessment: The case of China. Ocean Coast. Manag. 177, 166178. https://doi.org/10.1016/j.ocecoaman.2019.05.015

López, I., Pagán, J.I., Navarro-González, F.J., Müller, G. V., Aragonés, L., 2020. Determination of the study period necessary for calculating the equilibrium beach profile and the depth of closure. Appl. Ocean Res. 94, 102005. https://doi.org/10.1016/j.apor.2019.102005

Lu, J., 2010. Research Report on the Regional Climate of 908 Special Island Survey in Zhejiang Province.

Luijendijk, A., Hagenaars, G., Ranasinghe, R., Baart, F., Donchyts, G., Aarninkhof, S., 2018. The State of the World's Beaches. Sci. Rep. 8, 6641. https://doi.org/10.1038/s41598-018-24630-6

Luo, S., Liu, Y., Jin, R., Zhang, J., Wei, W., 2016. A guide to coastal management: Benefits and lessons learned of beach nourishment practices in China over the past two decades. Ocean Coast. Manag. 134, 207-215. https://doi.org/10.1016/j.ocecoaman.2016.10.011

McCave, I.N., 1972. Transport and escape of fine-grained sediment from shelf areas, in: Swift, D., Duane, D., Pilkey, O. (Eds.), Shelf Sediment Transport: Process and Pattern. Dowden, Hutchinson and Ross, New York, pp. 225-247.

Mouragues, A., Bonneton, P., Castelle, B., Marieu, V., Jak McCarroll, R., RodriguezPadilla, I., Scott, T., Sous, D., 2020. High-Energy Surf Zone Currents and Headland Rips at a Geologically Constrained Mesotidal Beach. J. Geophys. Res. 
663

664

665

666

667

668

669

670

671

672

673

674

675

676

677

678

679

680

681

682

683

Qi, H., Cai, F., Lei, G., Cao, H., Shi, F., 2010. The response of three main beach types to tropical storms in South China. Mar. Geol. 275, 244-254. https://doi.org/10.1016/j.margeo.2010.06.005

Schwab, W.C., Thieler, E.R., Allen, J.R., Foster, D.S., Swift, B.A., Denny, J.F., 2000. Influence of inner-continental shelf geologic framework on the evolution and behavior of the barrier-island system between Fire Island Inlet and Shinnecock Inlet, Long Island, New York. J. Coast. Res. 16, 408-422.

Seymour, R., Guza, R.T., O’Reilly, W., Elgar, S., 2005. Rapid erosion of a small southern California beach fill. Coast. Eng. 52, 151-158. https://doi.org/10.1016/j.coastaleng.2004.10.003

Shepard, D., 1968. A two-dimensional interpolation function for irregularly-spaced data, in: Proceedings of the 1968 23rd ACM National Conference, ACM 1968. Association for Computing Machinery, Inc, pp. 517-524. https://doi.org/10.1145/800186.810616

Short, Andrew D., Masselink, G., 1999. Embayed and structurally controlled embayed beaches., in: Short, A.D. (Ed.), Handbook of Beach and Shoreface Morphodynamics. Wiley, Chichester, pp. 230-250.

Stanley, D.J., Moore, G.T., 1983. The mudline: variability of its position relative to shelfbreak., in: The Shelfbreak: Critical Interface on Continental Margins. pp. 279-298.

Stanley, D.J., Wear, C.M.M., 1978. The "mud-line": An erosion-Deposition boundary 
684

685

686

687

688

689

690

691

692

693

694

695

696

697

698

699

700

701

702

703

704

705

on the upper continental slope. Mar. Geol. 28, M19-M29. https://doi.org/10.1016/0025-3227(78)90090-7

Third Institute of Oceanography, 2010. Coast erosion assessment and control: The final investigation and assessment.

Valiente, N.G., Masselink, G., Scott, T., Conley, D., McCarroll, R.J., 2019. Role of waves and tides on depth of closure and potential for headland bypassing. Mar. Geol. 407, 60-75. https://doi.org/10.1016/j.margeo.2018.10.009

Wang, L., Li, X., Xu, Z., 2011. Analysis on climatic characteristics of typhoon over the past 50 years at Zhoushan. Mar. Forecast. 28, 36-43.

Xia, X., 2014. China's Islands: Zhejiang (Volume II: Zhoushan Archipelago). China Ocean Press, Beijing.

Xu, X., Shen, Y., Mao, N., Zhang, L., 2018. Study on the sandy-muddy hybrid beach and sand-silt demarcation point: survey on the type of Xiamen Bay Beach. J. Hohai Univ. Nat. Sci. 46, 183-188. https://doi.org/10.3876/j.issn.10001980.2018.02.014

Yu, X., Gu, D., Yan, W., Xia, D., Du, J., Zhu, Z., Liu, S., 2016. Lateral Differences in Sediments and Geomorphology of the Northern and Southern Typical Sandy Coasts in the Eastern Shandong Peninsula and Their Genesis---Taking the Coasts of the Haiyang Wanmi Beach and the Weihai International Beach as the Example. China Coast. Eng. 35, 33-46.

Zhao, S., Cai, F., Qi, H., Zhu, J., Zhou, X., Lei, G., Zheng, J., 2020a. Contrasting sandmud transition migrations in estuarine and bay beaches and their potential 
$\begin{array}{llll}\text { morphological } & \text { responses. } & \text { Geomorphology } & 365,\end{array}$ https://doi.org/10.1016/j.geomorph.2020.107243

708 Zhao, S., Qi, H., Cai, F., Zhu, J., Zhou, X., Lei, G., 2020b. Morphological and sedimentary features of sandy-muddy transitional beaches in estuaries and bays along mesotidal to macrotidal coasts. Earth Surf. Process. Landforms 45, 16601676. https://doi.org/10.1002/esp.4837

712 Zhou, X., Cai, F., Qi, H., Wang, L., Zhao, S., Lei, G., Zhu, J., 2019. Comparative study of sand-mud transition on two sandy-muddy transitional beaches along west coast of the Taiwan Straits. Ocean Eng. 37, 133-140. 